\title{
Inbreeding depression under a competitive regime in Mimulus guttatus: consequences for potential male and female function
}

\author{
DAVID E. CARR* \& MICHELE R. DUDASH \\ Department of Plant Biology and Maryland Agriculture Experiment Station, University of Maryland, College Park, \\ MD 20742-5815, U.S.A.
}

\begin{abstract}
The effects of one generation of selfing and outcrossing on six life history characters were examined in the greenhouse for two populations of the mixed-mating species Mimulus guttatus. Inbreeding depression was not detected in the mass of seed produced by maternal plants, but selfing significantly reduced germination success by $13-20$ per cent relative to outcross seeds. Seedlings produced by self-pollination were $26-31$ per cent smaller than outcross progeny. Late life history stages were examined under varied competitive regimes in which each plant was grown with a neighbour of either an inbred or outbred individual. Progeny resulting from self-pollinations showed a 14-30 per cent reduction in ovule number per locule, and their pollen production per flower was reduced by 28-33 per cent. Adult above-ground biomass showed the greatest inbreeding depression, ranging from 24-50 per cent depending on the competitive conditions. Thus progeny resulting from selfing are smaller as adults and contribute significantly fewer potential gametes into the gene pool as pollen grains and ovules. The multiplicative effects of these characters is calculated. For all traits except ovule number, outcross progeny from parents of the same population did not differ significantly from outcross progeny produced by parents that came from populations separated by $10 \mathrm{~km}$, suggesting relatively little differentiation between populations. The relative performance of self and outcross progeny in later life history stages was independent of the relative performance observed in earlier stages.
\end{abstract}

Keywords: competition, inbreeding depression, mating system, Mimulus guttatus, ovule production, pollen production.

\section{Introduction}

Inbreeding depression has been invoked repeatedly as the major force preventing the invasion of selfing variants into outcrossing plant populations because it can counteract the 50 per cent transmission advantage inherent to selfing. When inbreeding depression is greater than 50 per cent, outcrossing should be maintained, whereas selfing is expected to evolve when inbreeding depression is less than 50 per cent (e.g. Maynard Smith, 1977; Charlesworth \& Charlesworth, 1979, 1987, 1990; Lloyd, 1979; Charlesworth, 1980; Lande \& Schemske, 1985; Charlesworth et al., 1990; but see Holsinger, 1988, 1991 and Uyenoyama \& Waller, 1991a,b,c for arguments against).

\footnotetext{
${ }^{*}$ Correspondence.
}

Although inbreeding depression has been estimated in many species (e.g. Schemske, 1983; Schoen, 1983; reviewed by Charlesworth \& Charlesworth, 1987; Ritland \& Ganders, 1987; Svensson, 1988; Griffing, 1989; Levin, 1989; Dudash, 1990; Holtsford \& Ellstrand, 1990; Fenster, 1991b; Johnston, 1992; Ågren \& Schemske, 1993) more information is needed on how the genetic makeup of immediate neighbours can affect the relative performance of self and outcross progeny and how the expression of inbreeding depression varies across life history traits.

Variation in plant density and in the genetic make-up of neighbours can alter the expression of inbreeding depression (e.g. Schmitt \& Ehrhardt, 1990; Wolfe, 1993). Because of limited seed dispersal, progeny from the same maternal plant are often nearest neighbours (e.g. Levin \& Kerster, 1969; Schaal \& Levin, 1978; Beattie \& Culver, 1979; 
Levin, 1981; Rai \& Jain, 1982; Fenster, 1991a). In plant species with mixed-mating systems this may result in self and outcross progeny competing directly with one another. If competition among sibs is reduced by greater phenotypic variation among sibs, McCall et al. (1989) predict that a mixed-mating system, which maximizes the potential phenotypic variation among sibs, would be favoured by selection. Therefore, investigations of the forces affecting the evolution of plant mating systems should not ignore the biotic interactions among progeny when evaluating the realized cost of selfing.

Inbred progeny show reduced performance across a wide variety of traits (e.g. Dudash, 1990; Johnston, 1992), but the measurement of inbreeding depression has been biased toward quantifying female function, partly because of the ease of data collection. Some data on pollen viability have been reported for Medicago (Dziubenko, 1983), Mimulus guttatus (Ritland \& Ganders, 1987; Willis, 1993b), and Vaccinium corymbosum (Krebs \& Hancock, 1990), but we still lack information on the effects of selfing on pollen production. Examining components of male and female function such as the production of pollen and ovules allows us to quantify the effects of inbreeding depression on potential gamete production beyond the commonly used fitness parameters such as total flower number per individual or a measurement of overall size, which is often significantly correlated to flower number (e.g. Jain, 1978; Kesseli \& Jain, 1984; Kalisz, 1989).

The goal of our study was to quantify the effects of one generation of enforced selfing and outcrossing on a number of early (seed mass per fruit, germination success, and seedling biomass) and late (pollen production per flower, ovule production per flower, adult above-ground biomass) life history traits in a species with a mixed-mating system, Mimulus guttatus. Cross-pollinations were made between populations as well as within populations in order to evaluate more fully the effect of outcrossing by reducing the relatedness between parents to nearly zero. Late life history stages were examined under varied competitive regimes to determine if neighbour effects influence the magnitude of inbreeding depression expressed by the progeny.

\section{Materials and methods}

\section{General procedures}

Mimulus guttatus DC. (Scrophulariaceae) is an annual to perennial hermaphroditic herb widely dis- tributed across western North America where it occupies moist habitats. The showy flowers are produced in pairs at each stem node. It is fully selfcompatible, and outcrossing rates measured for $M$. guttatus populations vary from 0.25 to 1.00 , averaging about 0.60 (Ritland \& Ritland, 1989; Ritland, 1990; Dudash \& Ritland, 1991; Willis, 1993a).

In 1988 single fruits were collected from plants at $1 \mathrm{~m}$ intervals along linear transects from two annual populations of $M$. guttatus (hereafter referred to as $\mathrm{S}$ and $\mathrm{T}$ ) located approximately $10 \mathrm{~km}$ apart in Lake and Mendocino counties, California. Dudash \& Ritland (1991) have estimated the outcrossing rate for population $\mathrm{T}$ to be $0.70(\mathrm{SE}=0.06)$, but no estimate is available for population S. Population T consisted of several hundred flowering individuals while population S numbered in the thousands. Seed from 27 and 28 maternal families from populations $\mathrm{S}$ and $\mathrm{T}$, respectively, were used for this experiment. All plants were raised in a pollinator-free greenhouse in College Park, MD with an $18 \mathrm{~h}$ photoperiod maintained with sodium vapour lights as needed. Plants were grown in $46 \mathrm{~cm}^{2}$ square plastic pots filled with Progro 300S soil and were bottom-watered without fertilizer.

In the summer of 1990,30 seeds from each fieldcollected maternal family were sown. One randomly selected seedling from each family was transplanted for use in hand-pollinations. Both self- and crosspollinations were accomplished by rubbing dehiscent anthers onto the stigma of the seed parent on the day of anthesis. Corollas and stamens were removed following hand-pollinations to prevent any subsequent self-pollination (Dole, 1990).

Two types of cross-pollinations were performed: crosses between individuals of the same population (WITHIN crosses) and crosses between individuals of the two different populations (BETWEEN crosses). One plant from each family served as a seed parent for one WITHIN and one BETWEEN cross. Pollen parents were chosen at random without replacement until each family had served as a pollen donor for one WITHIN and one BETWEEN cross. Cross-pollinations were not reciprocal. Self- and cross-pollinations were performed on different flowers at the same node to control for potential temporal and positional pollination effects. In order to distinguish those self-pollinations paired with WITHIN crosses from those paired with BETWEEN crosses, we use the notation SELFW and SELFB, respectively. Each maternal family therefore was comprised of four sets of seeds: WITHIN, SELFW, BETWEEN, and SELFB. 


\section{Estimation of inbreeding depression in early life history stages}

The effects of the pollination treatments were examined for three early life history stages: seed mass per fruit, germination success, and seedling biomass. Total seed mass per fruit for each pollination treatment was determined to the nearest $0.1 \mathrm{mg}$. Seed mass per fruit is significantly correlated to seed number in $M$. guttatus ( $r=0.87, n=30, P<0.001)$. On 1 February 1991, 30 seeds from the four pollination types of each maternal family were sown into individual pots in order to examine germination success, expressed as the proportion of seedlings emerging by day 15 . Three randomly chosen seedlings from each pot were dried and collectively weighed.

\section{Estimation of inbreeding depression in adult life history stages}

Three adult life history characters-ovule and pollen number, and above ground biomass-were measured on plants grown in pair-wise competition. Seedlings were chosen randomly within each maternal family and transplanted into a single replicate of the following six pair-wise combinations: WITHINWITHIN, WITHIN-SELFW, SELFW-SELFW, BETWEEN-BETWEEN, BETWEEN-SELFB, and SELFB-SELFB. Each pair of seedlings was placed in a single pot, and they were separated by approximately 20-30 mm. These six combinations were randomized within maternal families on the greenhouse bench. A second block was created to increase the replication of only the WITHINSELFW and BETWEEN-SELFB combinations of all maternal families.

Potential female function was estimated by collecting gynoecia from the first two flowers produced by each flowering plant. Ovules were counted from one of the two symmetrical locules from each pistil. A mean ovule number per locule was calculated for each plant and represents one-half the number of ovules in a single pistil. We will refer to this as ovule number.

Potential male function was estimated by collecting androecia from the third and fourth flower buds prior to pollen dehiscence. Pollen counts were made using an Elzone 280PC particle counter. A sample mean was calculated from three replicate subsamples. The sample mean is equivalent to $1 / 15$ of the total pollen production per flower, and we will refer to this as pollen number.

After two months of growth all plants were harvested at soil level, dried at $50^{\circ} \mathrm{C}$ for 1 week, and weighed. Adult above-ground biomass is significantly correlated to total flower number per plant in $M$. guttatus ( $r=0.342, P<0.0001, n=2558)$.

Because inbreeding effects are cumulative across the life cycle, it is appropriate to examine inbreeding depression in a multiplicative fashion (e.g. Schemske \& Pautler, 1984; Dudash, 1990; Fenster, 1991b; van Treuren et al., 1993). We included seed mass, the probability of germination, adult above-ground biomass, and pollen and ovule numbers in our multiplicative fitness function (MFF). For each character we calculated the ratio of self/outcross performance within each maternal family. The MFF equalled the product of these ratios. We calculated the geometric mean MFF across maternal families for each $M$. guttatus population. The population level of inbreeding depression based on our MFF is 1 minus this mean.

\section{Statistical analysis}

All data analysis was performed with sAS version 6.08 (SAS, 1989). In all ANOVA models, variation between populations and variation among maternal families were analysed as random effects. Variation among pollination treatments was analysed as a fixed effect. Two-way interactions were analysed as random effects. In all analyses, we used the SAS RANDOM statement with the TEST option to produce the error mean squares for hypothesis tests. Multiple comparisons among treatment means were made with a Ryan-Einot-Gabriel-Welsch multiple range test (Day \& Quinn, 1989).

The dependent variables seed mass, germination success, and seedling biomass were each analysed separately using the same mixed-model which included the effects of populations, maternal families nested within populations, pollination treatment, and a population $\times$ treatment interaction. Seed mass and seedling biomass were log-transformed and germination success was arcsine-transformed in order to meet ANOVA assumptions.

The analysis of competitive effects on the logtransformed biomass of adult plants included only data from the first block of the experiment. The model included the effects of populations, maternal families nested within populations, and treatments. Eight treatments were defined: (1) WITHIN grown with a SELFW, (2) BETWEEN grown with a SELFB, (3) WITHIN grown with a WITHIN, (4) BETWEEN grown with a BETWEEN, (5) SELFW grown with a SELFW, (6) SELFB grown with a SELFB, (7) SELFW grown with a WITHIN, and (8) SELFB grown with a BETWEEN. In those pots 
where a pair of plants of the same genetic type was grown (e.g. WITHIN-WITHIN pots), the biomass from a single plant was selected at random to be included in the analysis.

Pollen and ovule data from the WITHIN-SELFW and BETWEEN-SELFB pairs from both blocks of the experiment were analysed with the same mixedmodel which included the effects of blocks, maternal families, and pollination treatments. Only pairs where both individuals flowered were included in this analysis. No population effects or population $\times$ pollination interactions were detected for either character, and maternal families therefore were pooled across populations. Pollen number was logtransformed.

In order to examine whether within maternal lines the different life history traits were responding similarly to the pollination treatments, it was necessary to calculate a measure of relative performance of progeny produced from self and outcross pollinations. The relative performance of cross-types (RP) for all six characters within each maternal family was calculated as

$\mathrm{RP}=\frac{\text { (outcross-self) }}{\text { maximum }}$,

where maximum $=$ outcross when outcross $\geq$ self and maximum $=$ self when self $>$ outcross. This measure of RP ranges from 1 to -1 and can be summed in an unbiased fashion ( ̊gren \& Schemske, 1993). A separate calculation was made for WITHIN and BETWEEN outcrosses and their paired selfs. Using these family level estimates, the independence of RP observed for the six characters was tested using Pearson's correlation coefficient. Statistical significance was determined with a sequential Bonferroni test (Rice, 1989).

\section{Results}

Significant population differences were found only in the analysis of seedling biomass (see below), and no significant interactions between population and pollination treatment were detected, indicating that both populations responded similarly to the pollination treatments. Thus the data from the two populations have been pooled in the Tables and Figures.

The effects of pollination treatments on the early life history traits are listed in Table 1 . Seed mass did not vary significantly among pollination treatments $\left(F_{3,3}=3.17, P=0.1844\right)$. Outcross progeny germinated, on average, at a 17 per cent higher rate (13 per cent based on WITHIN crosses and 20 per cent
Table 1 The effect of self-pollination (SELFW and SELFB) on mean seed mass per fruit, germination success, and 15-day-old seedling biomass contrasted to the effect of cross-pollinations made between plants within the same population (WITHIN) and between plants of different populations (BETWEEN)

\begin{tabular}{lccc}
\hline $\begin{array}{l}\text { Pollination } \\
\text { treatment }\end{array}$ & $\begin{array}{c}\text { Seed mass } \\
\text { per fruit (mg) }\end{array}$ & $\begin{array}{c}\text { Per cent } \\
\text { germination }\end{array}$ & $\begin{array}{c}\text { Seedling } \\
\text { biomass (m) }\end{array}$ \\
\hline SELFW & $7.23^{\mathrm{a}}$ & $66.2^{\mathrm{a}}$ & $2.12^{\mathrm{a}}$ \\
WITHIN & $7.62^{\mathrm{a}}$ & $76.4^{\mathrm{b}}$ & $3.07^{\mathrm{b}}$ \\
SELFB & $8.62^{\mathrm{a}}$ & $62.2^{\mathrm{a}}$ & $2.23^{\mathrm{a}}$ \\
BETWEEN & $9.30^{\mathrm{a}}$ & $77.4^{\mathrm{b}}$ & $3.00^{\mathrm{b}}$ \\
\hline
\end{tabular}

Means were calculated across 55 families representing two Mimulus guttatus populations.

Means with different superscripts differ significantly $(P<0.05)$ using a Ryan-Einot-Gabriel-Welsch multiple range test.

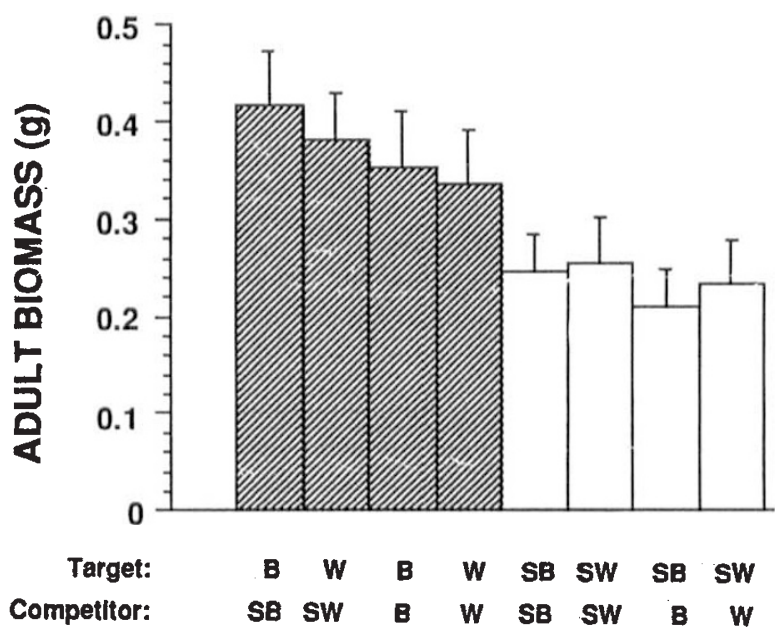

Fig. 1 Mean adult above-ground biomass for BETWEEN (B) and WITHIN (W) outcross plants and self (SB or SW) plants grown with different competitors. Means were calculated from 55 families representing two populations of Mimulus guttatus. Error bars represent upper 95 per cent confidence intervals. Different patterns among bars indicate significant differences $(P<0.05)$ based on a Ryan-Einot-Gabriel-Welsch multiple range test.

based on BETWEEN crosses) than self progeny $\left(F_{3,3}=19.29, P<0.0183\right)$. At the 15 -day-old seedling stage outcross progeny weighed, on average, 28 per cent more ( 31 per cent based on WITHIN crosses and 26 per cent based on BETWEEN crosses) than self progeny $\left(F_{3,3}=8.13, P<0.0001\right)$. The WITHIN and BETWEEN outcrosses did not differ significantly for any of these traits. Seedlings from popula- 
(a)

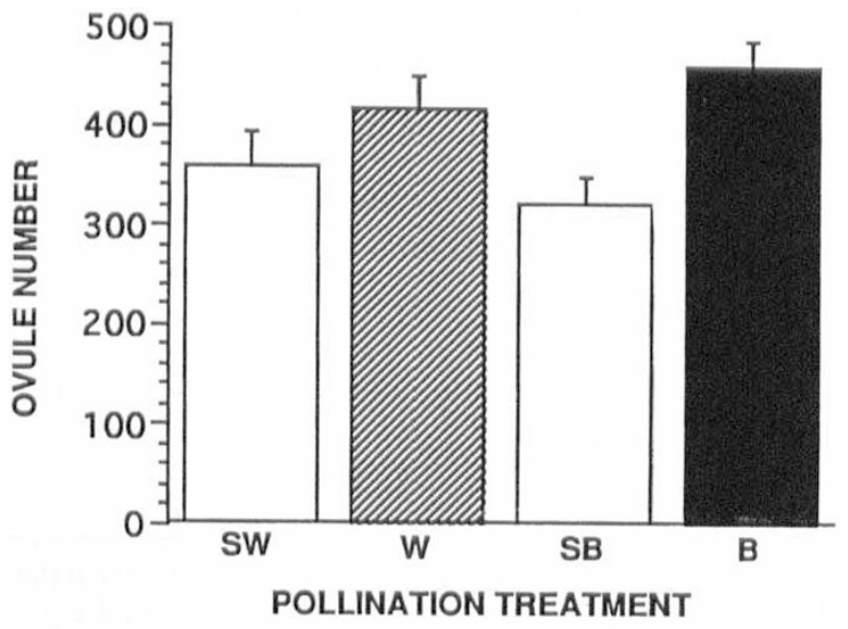

(b)

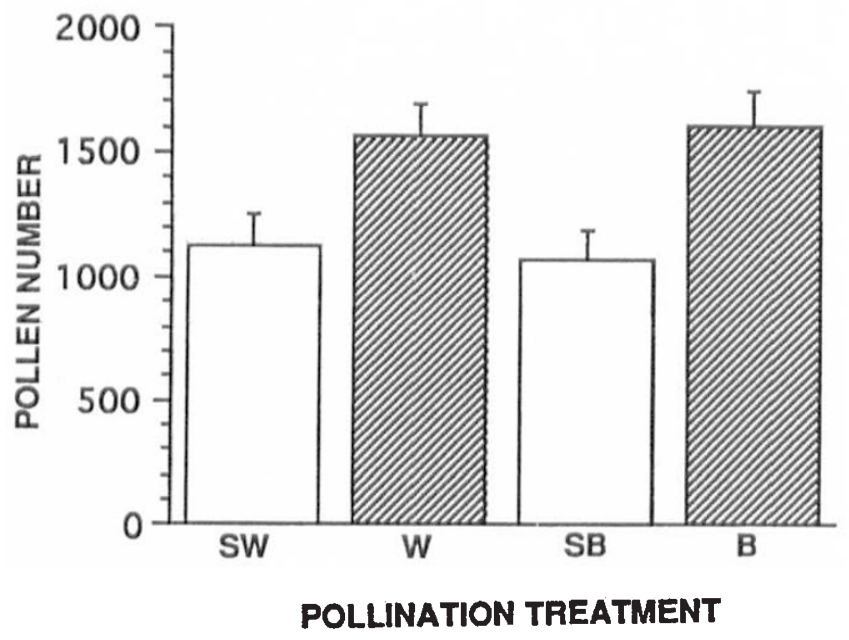

Fig. 2 Mean ovule number (a) and pollen number (b) of self (SELFW and SELFB) and outcross (WITHIN and BETWEEN) progeny. Ovule and pollen means were calculated from 45 and 53 families, respectively, pooled across the $\mathrm{S}$ and T populations of Mimulus guttatus. Ovule number represents $1 / 2$ of the total ovules produced per pistil. Pollen number represents $1 / 15$ th of the total pollen production per flower. Error bars represent upper 95 per cent confidence intervals. Different patterns among bars indicate significant differences $(P<0.05)$ based on a Ryan-Einot-Gabriel-Welsch multiple range test.

tion $S$ were significantly larger than those from population T $\left(F_{1,53}=5.34, P=0.0248\right)$, but the relative difference between self and outcross progeny did not differ significantly between populations.

There was significant variation in adult biomass among the plants grown with different competitors
$\left(F_{7,7}=13.14, P<0.0015\right)$. Plants competing with self progeny grew larger than plants of the same crosstype competing with outcross progeny (Fig. 1), but a multiple range test revealed significant differences only between the four outcrosses and the four selfs regardless of the neighbour's identity. Self progeny were, on average, 37 per cent smaller than outcross progeny. The greatest difference between self and outcross progeny (50 per cent) occurred when SELFB progeny were grown with BETWEEN progeny, and the smallest difference ( 24 per cent) was seen when paired SELFW progeny were compared with paired WITHIN progeny.

Because a significant difference among competitive regimes in adult above-ground biomass was not detected, the labour-intensive estimates of ovule and pollen number were made only for those plants in WITHIN-SELFW and BETWEEN-SELFB combinations. Mortality during the course of the experiment was low ( $<1$ per cent), but not all plants flowered before the experiment was terminated. Data on ovule and pollen number for plants that flowered from both blocks of the experiment were included in these analyses.

Ovule number for outcross progeny was, on average, 22 per cent (14 per cent based on WITHIN and 30 per cent based on BETWEEN; Fig. 2a) greater than progeny from self-pollinations $\left(F_{3,135}=14.60\right.$, $P<0.0001)$. A multiple range test revealed that progeny from BETWEEN crosses produced significantly more ovules than those from WITHIN crosses. Enforced selfing for one generation significantly reduced pollen number an average of 31 per cent ( 28 per cent based on WITHIN and 33 per cent based on BETWEEN; Fig. 2b) relative to progeny produced by outcrossing $\left(F_{3,161}=15.90, P<0.0001\right)$. The WITHIN and BETWEEN outcrosses did not differ significantly for pollen number.

The multiplicative effects of selfing on seed mass, germination success, adult biomass, and pollen and ovule number could result in substantial reductions in lifetime fitness. Self progeny from the $\mathrm{S}$ population perform only 27 per cent ( $S E=11$ per cent) and 7 per cent ( $\mathrm{SE}=3$ per cent) as well as outcross progeny derived from WITHIN and BETWEEN crosses, respectively, based on our MFF. Self progeny from the population $\mathrm{T}$ perform only 30 per cent $(\mathrm{SE}=12$ per cent) and 21 per cent $(\mathrm{SE}=10$ per cent) as well as outcross progeny derived from WITHIN and BETWEEN crosses, respectively.

Maternal families varied significantly for all six characters: seed mass per fruit $\left(F_{53,155}=2.95\right.$, $P<0.0001)$, germination success $\left(F_{53,155}=3.24\right.$, $P<0.0001)$, seedling biomass $\quad\left(F_{53,155}=3.11\right.$, 
Table 2 Pearson's correlation coefficients ( $r$ ) for the relative performance of cross-types (RP) among six life history characters

\begin{tabular}{|c|c|c|c|c|c|c|}
\hline & $\begin{array}{l}\text { Seed } \\
\text { mass }\end{array}$ & Germination & $\begin{array}{l}\text { Seedling } \\
\text { biomass }\end{array}$ & $\begin{array}{c}\text { Adult } \\
\text { biomass }\end{array}$ & Pollen & Ovules \\
\hline Seed mass & - & -0.047 & -0.149 & -0.070 & 0.267 & -0.020 \\
\hline Germination & 0.194 & - & 0.040 & -0.277 & 0.072 & 0.088 \\
\hline $\begin{array}{l}\text { Seedling } \\
\text { biomass }\end{array}$ & 0.034 & $P=0.0033$ & - & 0.219 & 0.181 & -0.144 \\
\hline $\begin{array}{l}\text { Adult } \\
\text { biomass }\end{array}$ & 0.113 & 0.013 & 0.296 & - & 0.304 & 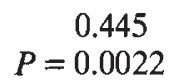 \\
\hline Pollen & 0.214 & 0.022 & 0.014 & 0.303 & - & 0.152 \\
\hline Ovules & 0.007 & 0.179 & 0.332 & $P=0.0002$ & 0.288 & - \\
\hline
\end{tabular}

Correlations were calculated across all 55 families from two Mimulus guttatus populations. Correlations above the diagonal were calculated from the WITHIN and SELFW crosses. Correlations below the diagonal were calculated on BETWEEN and SELFB crosses. Probability levels $(P)$ are reported only for those correlations exceeding the criteria of a sequential Bonferroni test ( $k=15$ for tests above and below the diagonal).

$\mathrm{P}<0.0001$ ), adult above-ground biomass $\left(F_{53,363}=2.91, \quad P<0.0001\right)$, ovule number $\left(F_{44,120}=1.80, \quad P=0.0064\right)$ and pollen number $\left(F_{52,142}=2.04, \quad P=0.0005\right)$. Because pollination treatments were replicated in the measurement of pollen and ovule number, we were able to test for an interaction between maternal family and pollination treatment. This interaction was significant for ovule number only $\left(F_{110,135}=1.62, P=0.0037\right)$ with the relative performance of cross-types for ovule number among maternal families ranging from 85 per cent to -63 per cent.

Pearson's correlations (Table 2) revealed that, within maternal families, relative performance of early life history traits (seed mass, germination success, and seedling biomass) was uncorrelated to RP in late life history traits (adult biomass and pollen and ovule number). Among the early traits examined, the only significant correlation was between $\mathrm{RP}$ in germination success and RP in seedling biomass based on the estimates from the BETWEEN outcrosses. Among the adult traits, only correlations between RP of biomass and RP in ovule number were significantly positive.

\section{Discussion}

Inbreeding depression can occur at any life history stage (e.g. Dudash, 1990; Johnston, 1992), and both biotic (e.g. Schmitt \& Ehrhardt, 1990; Wolfe, 1993) and abiotic (e.g. Dudash, 1990) conditions can influence the magnitude of inbreeding depression observed. We found the effects of selfing ranged from nonsignificant differences in seed mass per fruit to a 37 per cent reduction, on average, in adult above-ground biomass. Many researchers have quantified inbreeding depression in individual flower production, fruit production, and adult above-ground biomass (e.g. Schemske, 1983; Schoen, 1983; Dudash, 1990; Fenster, 1991b; Johnston, 1992), but few studies have examined allocation to potential male and female reproduction within a flower by quantifying pollen and ovule production (but see Karoly, 1991, 1994). We documented a 28-33 per cent reduction in pollen number and a 14-30 per cent reduction in ovule number. Not only are inbred plants smaller, producing fewer flowers and fruits (Dudash, Carr and Fenster, unpublished data), but each flower's potential to function as a male or female may also be reduced. A reduction in pollen stainability as an estimate of male function has been reported following selfing (Ritland \& Ganders, 1987; Krebs \& Hancock, 1990; Willis, 1993b), but we are unaware of other published studies where pollen production was used to compare self and outcross progeny.

Mean progeny fitness could be affected by the competitive environment of the seedlings. The 'elbow-room' hypothesis suggests that greater phenotypic variation among sibs could reduce competition and therefore increase mean progeny fitness (Young, 1981). This could lead to a selective advantage of mixed-mating systems because phenotypic variation may be maximized at intermediate levels of outcrossing (McCall et al., 1989). Competition among siblings of self and outcross origin may be a 
common phenomenon in $M$. guttatus because of its mixed-mating system (Ritland \& Ritland, 1989; Ritland, 1990; Dudash \& Ritland, 1991; Willis, 1993a), but the data from our competition study and those presented by others (Schmitt \& Ehrhardt, 1990; Argyres \& Schmitt, 1992) do not support this application of the elbow-room hypothesis. We found that the difference in performance between self and outcross progeny was greatest when self and outcross progeny were grown together, although the differences among competitive regimes fell short of significance. It appears that fitness of self progeny may be further reduced by competition, counteracting the advantage of greater 'elbow-room' gained from increasing phenotypic variability.

The relative performance of self and outcross progeny in later life history stages was independent of the relative performance observed in earlier stages. Significant correlations were observed only between RP for germination success and RP for seedling biomass and between RP for ovule number and RP for adult above-ground biomass. Such correlations suggest linkage and/or the pleiotropic effects of loci contributing to these traits. For example, the biomass and ovule correlation could reflect an overall reduction in the ability of inbreds to assimilate resources. The complete lack of correlations observed between early and late life history traits suggests that a number of loci are likely to make independent contributions to the genetic load affecting these traits. The interpretation of correlations between germination and the other life history traits may be complicated because those genotypes that failed to germinate are not represented later in the life cycle, but the correlations among the other traits are relevant because the estimates are drawn from the same statistical population.

It is important to note that these measures of inbreeding depression from the greenhouse are likely to be conservative estimates of the inbreeding depression that plants express in the field (Dudash, 1990). However, Willis (1993a) observed little difference in inbreeding depression between greenhouse and field-grown M. guttatus. Dole \& Ritland (1993) have reported an 81 per cent reduction in fitness of self $M$. guttatus progeny based on multigenerational changes in population inbreeding coefficients estimated from allozyme data. Such a high estimate of inbreeding depression is likely to be a reflection of the effect of the field environment and the multiplicative effects of many life history traits. Multiplicative effects across life history traits produced estimates of inbreeding depression greater than 60 per cent in the two populations of $M$. guttatus studied by Willis (1993a), and our estimates of multiplicative effects suggest inbreeding depression ranging from 71-93 per cent.

The effect of interparent distance on offspring performance has been used to detect the scale of genetic differentiation within and between plant populations (e.g. Sobrevila, 1988; Waser \& Price, 1989; Fenster, 1991b; van Treuren et al., 1993). If plants within populations share deleterious alleles because of common ancestry, crosses made between populations can show greater heterosis than those made within populations. Offspring from our withinand between-population crosses did not differ significantly in performance for most traits, including our MFF, suggesting little genetic differentiation between the two Mimulus study populations. The sole exception, ovule number, showed significantly greater heterosis in crosses made between populations relative to crosses made within populations.

Significant variation among maternal families was found for all characters, and this is likely to reflect genetic differences among maternal families as well as maternal effects (Falconer, 1981). The significant interaction between maternal families and pollination treatments observed in ovule number indicates that families differ in the magnitude of inbreeding depression expressed. Such differences could reflect variation among families in their past histories of inbreeding (Holsinger, 1988, 1991; Uyenoyama \& Waller, 1991a,b,c), but they also could reflect differences arising from specific combining ability between the pollen donor and recipient (Falconer, 1981), biparental inbreeding or even additive genetic differences among the sires. A project that will distinguish between these possibilities is currently underway in the $\mathrm{S}$ and $\mathrm{T}$ populations (Fenster, Carr and Dudash, unpublished data).

\section{Acknowledgments}

An NSERC grant through K. Ritland of the University of Toronto sponsored M.R.D.'s collection of the parental seed for this study. We thank C. Fenster, C. Galen, L. Galloway, D. Gill, K. Karoly, S. Weller, and two anonymous reviewers for their comments on earlier versions of this manuscript. We are grateful for the laboratory and greenhouse assistance from T. Cannizzaro, R. Gilbert, S. Mok, D. Nguyen, I. Otero, J. Park, A. Parker, and M. Sanchez. Computer time for this project was supported in full through the facilities of the Computer Science Center at the University of Maryland. Funding for this study was provided by a grant from the Maryland Agriculture Experiment Station to M.R.D. and 
by NSF grant DEB9220906 to M.R.D. This is scientific article number A-6467, contribution number 8670, from the Maryland Agriculture Experiment Station, Department of Botany.

\section{References}

ÅGREN, J. AND SCHEMSKE, D. w. 1993. Outcrossing rate and inbreeding depression in two annual monoecious herbs, Begonia hirsuta and B. semiovata. Evolution, 47, 125-135.

ARGYRES, A. AND SCHMITT, J. 1992. Neighbor relatedness and competitive performance in Impatiens capensis (Balsaminaceae): test of the resource partitioning hypothesis. Am. J. Bot., 79, 181-185.

BEATTIE, A. J. AND CULVER, D. C. 1979. Neighborhood size in Viola. Evolution, 33, 1226-1229.

CHARLESWORTH, B. 1980. The cost of sex in relation to mating system. J. Theor. Biol., 84, 655-671.

CHARLESWORTH, D. AND CHARLESWORTH, B. 1979. The evolutionary genetics of sexual systems in flowering plants. Proc. $R$. Soc. B, 205, 513-530.

CHARLESWORTH, D. AND CHARLESWORTH, B. 1987. Inbreeding depression and its evolutionary consequences. Ann. Rev. Ecol. Syst., 18, 237-268.

CHARLESWORTH, D. AND CHARLESWORTH, B. 1990. Inbreeding depression with heterozygote advantage and its effect on selection for modifiers changing the outcrossing rate. Evolution, 44, 870-888.

CHARLESWORTH, D., MORGAN, M. T. AND CHARLESWORTH, B. 1990. Inbreeding depression, genetic load, and the evolution of outcrossing rates in a multilocus system with no linkage. Evolution, 44, 1469-1489.

DAY, R. W. AND QUINN, G. P. 1989. Comparison of treatments after an analysis of variance in ecology. Ecol. Monogr., 59, 433-463.

DOLE, J. A. 1990. Role of corolla abscission in delayed selfpollination of Mimulus guttatus (Scrophulariaceae). Am. J. Bot., 77, 1505-1507.

DOLE, J. A AND RITLAND, K. 1993. Inbreeding depression in two Mimulus taxa measured by multigenerational changes in the inbreeding coefficient. Evolution, 47, 361-373.

DUDASH, M. R. 1990. Relative fitness of selfed and outcrossed progeny in a self-compatible, protandrous species, Sabatia angularis L. (Gentianaceae): a comparison in three environments. Evolution, 44, 1129-1139.

DUDASH, M. R. AND RITLAND, K. 1991. Multiple paternity and self-fertilization in relation to floral age in Mimulus guttatus (Scrophulariaceae). Am. J. Bot. 78, 1746-1753.

DZIUBENKO, N. 1. 1983. Influence of inbreeding and selection on pollen fertility of individual alfalfa clones. Trudy Po Prikladnoi Botanike, Genetike I Selektsii, 74, 95-100.

FALCONER, D. S. 1981. Introduction to Quantitative Genetics, 2nd edn. Longman, London.

FENSTER, C. B. 1991a. Gene flow in Chamaecrista fasciculata (Leguminosae) I. Gene dispersal. Evolution, 45, 398-409.
FENSTER, C. B. 1991b. Gene flow in Chamaecrista fasciculata (Leguminosae) II. Gene establishment. Evolution, 45, 410-422.

GRIFFING, B. 1989. Genetic analysis of plant mixtures. Genetics, 122, 943-956.

HOLSINGER, K. E. 1988. Inbreeding depression doesn't matter: the genetic basis of mating system evolution. Evolution, 42, 1235-1244.

HOLSINGER, K. E. 1991. Inbreeding depression and the evolution of plant mating systems. Trends Ecol. Evol., 6, 307-308.

HOLTSFORD, T. P. AND ELLSTRAND, N. C. 1990. Inbreeding effects in Clarkia tembloriensis (Onagraceae) populations with different outcrossing rates. Evolution, 44, 2031-2046.

JAlN, s. K. 1978. Breeding system in Limnanthes alba: several alternative measures. Am. J. Bot., 65, 272-275.

JoHnston, M. O. 1992. Effects of cross- and self-fertilization on progeny fitness in Lobelia cardinalis and $L$. siphilitica. Evolution, 46, 688-702.

KALISZ, s. 1989. Fitness consequences of mating system, seed weight, and emergence date in a winter annual, Collinsia verna. Evolution, 43, 1263-1272.

KAROLY, K. M. 1991. Causes and Consequences of IntraPopulational Variation in Mating System of Lupinus nanus. Ph.D. Dissertation, University of Chicago.

KAROLY, K. M. 1994. Inbreeding effects on mating system traits for two species of Lupinus (Leguminosae). Am. J. Bot., 81, 1538-1544.

KESSELI, R. AND JAIN, S. K. 1984. An ecological genetic study of gynodioecy in Limnanthes douglasii (Limnanthaceae). Am. J. Bot., 71, 775-786.

KREBS, S. L. AND HANCOCK, J. F. 1990. Early-acting inbreeding depression and reproductive success in the highbush blueberry, Vaccinium corymbosum L. Theor. Appl. Genet., 79, 825-832.

LANDE, R. AND SCHEMSKE, D. w. 1985. The evolution of self-fertilization and inbreeding depression in plants. I. Genetic models. Evolution, 39, 24-40.

LEVIN, D. A. 1981. Dispersal versus gene flow in plants. Ann. Mo. Bot. Gard., 68, 233-253.

LEVIN, D. A. 1989. Inbreeding depression in partially selffertilizing Phlox. Evolution, 43, 1417-1423.

LEVIN, D. A. AND KERSTER, H. w. 1969. Density-dependent gene dispersal in Liatris. Am. Nat., 103, 61-74.

LLOYD, D. G. 1979. Some reproductive factors affecting the selection of self-fertilization in plants. Am. Nat., 113, $67-79$

MAYNARD SMITH, J. 1977. The sex habit in plants and animals. In: Christiansen, F. B. and Fenchel, T. M. (eds) Measuring Selection in Natural Populations, pp. 265-273. Springer-Verlag, Berlin.

MCCALL, C., MITCHELL-OLDS, T. AND WALLER, D. M. 1989. Fitness consequences of outcrossing Impatiens capensis: tests of the frequency-dependent and sib-competition models. Evolution, 43, 1075-1084.

RAI, K. N. AND JAIN, s. K. 1982. Population biology of Avena IX. Gene flow and neighborhood size in relation to microgeographic variation in Avena barbata. Oecolo- 
gia, 53, 399-405.

RICE, w. R. 1989. Analyzing tables of statistical tests. Evolution, 43, 223-225.

RITLAND, K. 1990. Inferences about inbreeding depression based on changes of the inbreeding coefficient. Evolution, 44, 1230-1241.

RITLAND, K. AND GANDERS, F. R. 1987. Crossability in Mimulus guttatus in relation to components of gene fixation. Evolution, 41, 772-786.

RITLAND, C. AND RITLAND, K. 1989. Variation of sex allocation among eight taxa of the Mimulus guttatus species complex (Scrophulariaceae). Am. J. Bot., 76, 1731-1739.

SAS INSTITUTE. 1989. SAS/sTAT User's Guide, Version 6, 4th edn, vol. 2. SAS Institute, Cary, NC.

SCHAAL, B. A. AND LEVIN, D. A. 1978. Morphological differentiation and neighborhood size in Liatris cylindracea. Am. J. Bot., 65, 923-928.

SCHEMSKE, D. W. 1983. Breeding system and habitat effects on fitness components in three neotropical Costus (Zingiberaceae). Evolution, 37, 523-539.

SCHEMSKE, D. W. AND PAUTLER, L. P. 1984. The effects of pollen composition on fitness components in a neotropical herb. Oecologia, 62, 31-36

sCHMITT, J. AND EHRHARDT, D. W. 1990. Enhancement of inbreeding depression by dominance and suppression in Impatiens capensis. Evolution, 44, 269 - 278.

SCHOEN, D. J. 1983. Relative fitnesses of selfed and outcrossed progeny in Gilia achilleifolia (Polemoniaceae). Evolution, 37, 292-301.

SOBREVILA, c. 1988. Effects of distance between pollen donor and pollen recipient on fitness components in Espeletia schultzii. Am. J. Bot., 75, 701-724.

SVENSSON, L. 1988. Inbreeding, crossing and variation in stamen number in Scleranthus annuus (Caryophyllaceae), a selfing annual. Evol. Trends Plants, 2, 31-37.

UYENOYAMA, M. AND WALLER, D. M. 1991a. Coevolution of self-fertilization and inbreeding depression. I. Mutation-selection balance at one and two loci. Theor. Pop. Biol., 40, 14-46.

UYENOYAMA, M. AND WALleR, D. M. 1991b. Coevolution of self-fertilization and inbreeding depression. II. Symmetric overdominance in viability. Theor. Pop. Biol., 40, 47-77.

UYENOYAMA, M. AND WALLER, D. M. 1991c. Coevolution of self-fertilization and inbreeding depression. III. Homozygous lethal mutations at multiple loci. Theor. Pop. Biol., 40, 173-210.

VAN TREUREN, R., BULSMA, R., OUBORG, N. J. AND VAN DELDEN, w. 1993. The significance of genetic erosion in the process of extinction. IV. Inbreeding depression and heterosis effects caused by selfing and outcrossing in Scabiosa columbaria. Evolution, 47, 1669-1680.

WASER, N. M. AND PRICE, M. V. 1989. Optimal outcrossing in Ipomopsis aggregata: seed set and offspring fitness. Evolution, 43, 1097-1109.

wILlIs, J. H. 1993a. Partial self-fertilization and inbreeding depression in two populations of Mimulus guttatus. Heredity, 71, 145-154.

wILLIS, J. H. 1993b. Effects of different levels of inbreeding on fitness components in Mimulus guttatus. Evolution, 47, 864-876.

wOLFE, L. M. 1993. Inbreeding depression in Hydrophyllum appendiculatum: role of maternal effects, crowding, and parental mating history. Evolution, 47, 374-386.

YOUNG, J. P. W. 1981. Sib competition can favour sex in two ways. J. Theor. Biol., 88, 755-756. 